\title{
Understanding and Mis-understanding in Language in Brian O'Nolan's An Béal Bocht and Cruiskeen Lawn
}

\author{
Julieta Abella \\ University of Buenos Aires, Argentina
}

Copyright (c) 2020 by Julieta Abella. This text may be archived and redistributed both in electronic form and in hard copy, provided that the author and journal are properly cited and no fee is charged for access.

\begin{abstract}
Brian O'Nolan, part of the so-called Irish Modernism that arose at the same time as the declaration of the Republic, finds his literary form traversed by the question of Irish identity and materializes it in the "awesome jaggedness and seeming formlessness" (Kiberd 266-267) of his prose. Language, particularly in An Béal Bocht and Cruiskeen Lawn, explores its status and understanding, both in an imaginary Gaeltacht and in scenes from everyday life, respectively. This article seeks to read three different types of language apprehension in Brian O'Nolan's work: "faint-understanding", "misunderstanding" and "over-understanding". These three forms of understanding are how the author questions the pure and strict learning of language, revealing the complexity of acquiring communicational expertise and highlighting the linguistic threshold where English and Irish coexist and struggle.
\end{abstract}

Key Words. Brian O’Nolan, Irish, Language, Understanding, An Béal Bocht, Cruiskeen Lawn.

Resumen. Brian O’Nolan fue parte del así llamado modernismo irlandés que surgió al mismo tiempo que la declaración de la república. Su escritura se ve atravesada por la cuestión de la identidad irlandesa y se materializa en la "asombrosa asimetría y aparente falta de forma" (Kiberd 266-267) de su prosa. El lenguaje, principalmente en An Béal Bocht y en Cruiskeen Lawn, explora su estatus y su comprensión, tanto en un imaginario país donde se habla el gaélico como en escenas de la vida cotidiana, respectivamente. En este artículo se examinan tres tipos distintos de aprehensión del lenguaje en la obra de Brian O'Nolan: "la comprensión insuficiente", "la incomprensión" y "la comprensión en exceso". Estas tres variedades de comprensión constituyen la forma en la que el autor cuestiona el aprendizaje puro y estricto del idioma, revelando a su vez la complejidad que supone adquirir una destreza comunicacional y destacando el marco lingüístico donde el inglés y el irlandés coexisten y se enfrentan.

Palabras clave. Brian O’Nolan, idioma irlandés, lenguaje, comprensión, An Béal Bocht, Cruiskeen Lawn.

"Do you not know your own language, you ignorant man?" 
Rhapsody in Stephen's Green, Flann O'Brien

In the 1942 edition of Éire: Bliainiris Ghaedheal, Ciarán Ó Nualláin states that "when the history of the revival of Irish comes to be written, ... the year 1940 will be seen as the time when it was at its lowest ebb and closest to extinction" (Ó Conaire 123). Yet, amidst the condemnation conceived within the language movement of the time, that particular year saw the writing of what scholars and readers have regarded as one of the best novels written in the Irish language: Myles na gCopaleen's An Béal Bocht.

The period of the 1940s also saw the commencement of Cruiskeen Lawn, a column that would be published for the following 26 years in the pages of the Irish Times. During the first years of regular publication, as Taaffe suggests, "this Irish period of Cruiskeen Lawn - as in the novel it inspired, An Béal Bocht - O'Nolan astutely intervened in contemporary debates within the language movement" (91). Language, in this manner, not only functions as a primary source of communication but, simultaneously, as a critical reference in disseminating and preserving the values that are concurrent within a certain cultural field. As Jacques Derrida asserts, language functions by producing events that maintain life through repetitions "and that ensure traditio" ("Who or What Is Compared?" 24). Thus, O'Nolan, first, with Cruiskeen Lawn and, then, with An Béal Bocht, fully acknowledges and places himself in the literary scene around the language matter of the time.

Particularly, O'Nolan explores the problem of language in what can be read as three different types of understanding: "faint-understanding", "misunderstanding" and "overunderstanding". The three categories mentioned above were set forth first-hand for this particular critical reading and can be found in particular scenes of An Béal Bocht and, similarly, in some columns of Cruiskeen Lawn. Consequently, assuming that the comprehension and use of language is a fundamental process in the propagation of a given cultural context, these forms of understanding exhibit how O'Nolan questions the pure and strict learning of language, through a multilingual pastiche, revealing the complexity of acquiring and communicating coexisting languages, such as English and Irish.

\section{An Béal Bocht and Cruiskeen Lawn}

As mentioned before, An Béal Bocht was published in 1941 and had a great commercial success directly after its printing. According to McKibben, Myles' "parodic depiction of Gaelic squalor and self-perpetuated suffering in the life-story of Bonaparte O'Coonassa programmatically attacks the baggage associated with the Irish language and the regions where it continued to be spoken" (106). An Béal Bocht was Myles' first and only novel written in the Irish language. Its title, as Kiberd correctly notes, refers to a common expression "used to describe the slavish tactic of the person who makes a great show of poverty" (502-503). Its use is directly linked to the pursuit of gaining sympathy from the listener and it is traditionally uttered in places hit by poverty. The words "listener" and "uttered" are employed here as Irish is primarily and more frequently used in a domestic and oral form, rather than in writing. Furthermore, this is emphasized by the subtitle of the book droch-scéal ar an droch-shaol: "a bad story about the hard life".

The novel is set in Corkadoragha, a fictional Gaeltacht, where Bonaparte O'Coonassa lives. The events that are told follow his life and the happenings of this town. Undoubtedly, there is intertextuality with, and a parody of, ${ }^{1}$ Gaelic texts of the Irish Literary Revival. This is particularly true of Ó Criomhthain's An t-Oileánach, ${ }^{2}$ where a life of misfortunes is told in the form of a biography. Taaffe furthers on this notion by saying that

In the novel, O'Nolan did not simply expose how formulaic and cliched the style of writing fostered by $\mathrm{O}$ Laoghaire has become. Parodying the new genre of the Gaeltacht 
autobiography, An Béal Bocht exaggerated its literary conventions and undermined the very notion of authenticity and artlessness which O Laoghaire fetishized. (101)

An Béal Bocht, additionally, as McKibben suggests, seeks to "answer in a 'conclusive' manner that most vexed and controversial of National-Myth Questions: 'What is an Irishman or Gael?'" (131). Hence, the novel parodies the nationalist literary tradition and, at the same time, questions the concerns involved in the language and cultural issues of the time.

Yet, in the words of Taaffe, "An Béal Bocht was published in December 1941, but it has long been anticipated by the parodies of folklore and Gaeltacht literature in Cruiskeen Lawn" (101). Cruiskeen Lawn, first published on 4 October 1940, was a response to the state of the Irish language. This first column responds to this idea that it would be impossible to revive the Irish language "unless conversations could be limited to requests for food and drink and other expressions of the elementary wants of life". In turn, the lexical possibilities of Irish are addressed by Myles in the following way: "Tá a lán rudaí gan I nGaedhilg, agus má bhíonn an léitheoir foighdeach, deirfear anseo iad ... Beidh aiste beag scigiúil ... lá amháin agus aiste mór neamh'scigiúil lá eile", which can be translated as "There are many things which are not said in Irish, and if the reader be patient, they will be said here. There will be a little mocking essay one day and a big non-mocking essay another day" (Ó Conaire 122). Thus, Cruiskeen Lawn, as stated in this column, became the perfect scenario to experiment with the Irish language and to criticise those who limited and restrained the linguistic and semantic possibilities of that given language due to inefficient political measures or to cultural prejudice.

Through the years, as mentioned, the column was in itself provocative and harsh over all Irish related matters. The column was commissioned by Bertie Smyllie and it appeared mostly in Irish during the first year. During the following years, and until 1943, the language publication alternated between Irish and English, yet, after that given year, it was published mostly in English. As a result, Cruiskeen Lawn, is set forth as a publication dominated by the coexistence of both Irish and English and presenting "a dialogue with his readers and (often) responding directly to them, bringing disparate discourses and opinions into conflict and colloquy" (Gillespie 171). This language coexistence found in Myles' columns demonstrates how the status of language can also be related, as mentioned before, to the different discourses that parody literary tradition in An Béal Bocht.

While Cruiskeen Lawn is signed, during its extensive publication, mostly under the name of Myles na Gopaleen, in the case of An Béal Bocht, the name Myles na gCopaleen is used. Thus, O'Nolan's use of pseudonyms is witty and deeply rooted in the text production they pair with. Furthermore, the name in itself, both Myles na Gopaleen and Myles na gCopaleen, is unmistakably related to its Irish descriptive nature, as it derives from na gcapaillín, an Irish phrase that can be translated as "of the little horses". On the other hand, Flann O'Brien is used by the author in the case of most of his English production with novels like At Swim-Two-Birds. Undoubtedly, these "pseudonyms were more than obligatory devices" (Coulouma 98). Brian O'Nolan, thus, introduces his work and his authorial figure in an intersection of dilemmas and traditions commencing with his selection and use of names and pseudonyms, which, simultaneously respond to different types of readers for his different texts. ${ }^{3}$

\section{Language and Irish Matters}

Yet, as mentioned in Cruiskeen Lawn, concerns regarding the coexistence of different languages are not exclusively related to the situation of Irish, and its relationship to English, during the $20^{\text {th }}$ century. The junction of all languages into one is circumscribed in one of the 
earliest forms of western literature. As narrated in Genesis 11:1-9, only one language was spoken before the inhabitants of the whole earth were confounded and could not understand each other any longer. Derrida sees this origin myth as a demonstration on how languages function in relation to others, as it "exhibits an incompletion, the impossibility of finishing, of totalizing, of saturation" ("Des Tours de Babel" 165). The limits within languages, then, are not distinctively visible, leading to an impossibility of strict categorization. And, in this way, there is a need to "consider the possibility for languages to be implicated [in] more than two in a text" (Derrida, "Des Tours de Babel" 171). Thus, the coexistence of languages is innate to the use of speech, enabling the conjunction among them despite possible dissimilarities.

Brian O'Nolan's writing can be seen as a significant illustration of how dissimilar languages can coexist within speech, both concordant and problematically, as his texts question "the very definition of meaning and human language" (Coulouma 10). His prose unfolds in a "mocking miachstúir of English-Irish or English speilt as Irish" (O'Neill XIV). O'Nolan, not only uses both languages fluently in his writing but creates a pastiche in which both languages stimulate each other by creating new forms that reproduce their coexistence. This can be seen, particularly, in Cruiskeen Lawn, where Myles, along these lines, spells English and Irish phonetically - "Nao, not rahlly" (The Best of Myles 111) - or introduces other languages such as German - "Ersatz Irish Literature"” (269) - or even Latin - "ALTERVM jam faeculum ad finem vegit" (284) -. ${ }^{4}$ Thus, Cruiskeen lawn presents "multilingual puns and deliberate mistranslations" (Kager 60) to play within, and beyond, the limits of different languages but mainly with Irish and English.

\section{Understanding}

How does the coexistence of languages in O'Nolan's writing question a certain status of Irish culture and, particularly, the use of the Irish language? As previously mentioned, concerning the publishing context of An Béal Bocht, frustration over the state and use of the Irish language is one of the elements that assemble the parodic form of the text. O'Nolan describes the failure of the language revival following the establishment of the Irish Free State with the following words: "there is something comic about revivalists who have no idea of what they are trying to revive" (in Cronin 144). The novel, as mentioned before, serves as a parody of its literary scene and, especially, regarding the linguistic revivalism of the time. On one hand, the author uses parody, particularly, in the figure of Bonaparte O'Coonassa, as "the Irishman becomes a parody of himself ... a walking cliché" (Taffee 104). On the other hand, "It might also be mentioned that while An Béal Bocht is in its general tendency a social and literary satire. It is also a medium for the independent exercise of the comic, imaginative and anarchic sensibilities of its author" (Ó Conaire 137).

Myles' Irish novel, unquestionably, maintains and enlarges the language issue already depicted in other works, ${ }^{5}$ specifically, by portraying a fictional Irish speaking area, Gaeltacht, and its dealings with the rest of English-speaking Ireland. The novel is, in itself, written in playful Irish, infused by English, with "a number of dialect forms [which] are, in fact, used in the book and the language, though not wholly accurate" (Ó Conaire 139). Moreover, the text presents no complete understanding of the linguistic and fictional exchanges found in the text.

Considering the whimsical and problematic use of the Irish language, O'Nolan believed in the "untranslatability" of the novel as there was no use in translating something that was meant to be in Irish. Despite being published in 1941, An Béal Bocht was translated only once to the English language about thirty years later after its first printing, in 1973, by Patrick C. Power. One of the problems of his translation, Donohue notes, is that "alliteration disappears in the English, as does the game of translating into English some of the more fanciful appellations" (70). 
Yet, as suggested before, O'Nolan's questioning over language not only lies within the linguistic layer of the matter and its "translatability". In An Béal Bocht, the characters' approach, both to Irish and English is problematic, illustrating the complex but also concrete coexistence of these two languages. This can be seen not only in the situations that occur to the main character, Bonaparte O'Coonassa, but also in the episodes involving the community of Corkadoragha as a whole.

The problematic coexistence of languages, as mentioned before, can also be read in the first Cruiskeen Lawn column. Both languages are used within the same text and the narrative voice shifts between one and the other without acknowledging this to the reader "One can say it several ways - Ciabh aráin an duine-uasail Uí Mhuilibh. Manna Rúiseach. Rúiskeen Lawn". ${ }^{6}$ Hence, this column establishes itself as a setting where this linguistic infection can occur smoothly, emphasizing the complexity of this linguistic coexistence. Because Cruiskeen Lawn was published for 26 years, the different uses, and misuses, of language(s) vary and are presented differently in the columns. Yet, through the years, the whimsical presence of diverse languages in relation to concrete speech interactions are persistently repeated. In this manner, these scenes found in An Béal Bocht and Cruiskeen Lawn can be read under three different types of language understanding that illustrate the complexity within the conjunction of the Irish and the English sphere.

The concept of understanding provides a theoretical angle that allows an approach to these occurrences of linguistic overlap. Understanding can be defined as the "knowledge about a subject, situation, etc. or about how something works". ${ }^{7}$ Likewise, Bakhtin furthers on the act of understanding: "it assimilates the word to be understood into its own conceptual system filled with specific objects and emotional expressions" (272). The first meaning will serve as the crucial indicator of the terms used, while the definition provided by Bakhtin will enhance the reading of the texts within their specific cultural context. Specifically, this idea of language apprehension is questioned in O'Nolan's work because it presents the "mistrust of language as an instrument of knowledge and literal representation of the world" (Coulouma 100).

Moreover, three terms are suggested which build their significance with their prefixes and how they add to the original meaning of the word. First, "faint-understanding", which can be read like a low understanding, where what is being said is understood but not completely. Then, "misunderstanding", which is the failure to understand something clearly. And, finally, "over-understanding" refers to words that spread great expertise over the things said, yet they exaggerate and distort the facts they are talking about. Thus, these three terms can be thought of as a scale, in which "misunderstanding" is positioned between a word that portrays this to a lesser extent, as in "faint-understanding", or to a greater degree, as in "over-understanding".

These three terms and their significance in O'Nolan's complex take on the language issue will be analysed in relation to three scenes of An Béal Bocht, which take place in chapters three and four, and, subsequently, to several columns found in Cruiskeen Lawn.

\section{4. "faint-understanding"}

The concept of "faint-understanding", as it has already been mentioned, stands for a type of slight understanding, where the listener is not entirely aware of the implications of what he/she is listening. Yet, there is an incomplete comprehension from the listener which separates this term from "misunderstanding". As the prefix suggests, this term commits with slight manners of misconception that enhance the distance between speech and reality.

In An Béal Bocht, the first day of school of Bonaparte O'Coonassa is narrated in chapter three - "I was seven years old when I was sent to school". The teacher, Osborne O'Loonassa, had a "ferocity of anger [that] stood on his forehead as permanent as his hair and he cared not a whit for anyone" (The Poor Mouth 29). Rather than a delightful anecdote, the events narrated 
during this first day portray the violence and authority of the colonial norm, as the teacher asks each of the students their name. This is answered by Bonaparte with a reference to his relatives rather than the use of a surname-"Bonaparte, son of Michelangelo, son of Peter, son of Owen ..." (30). And, after the teacher beats him, he declares "Yer nam is Jams O’Donnell!" (31). By telling each student in Corkadoragha that their name is "Jams O'Donnel", the teacher disintegrates the identity of the youth. In Long's words, this is because "individual identities are irrelevant before the overriding narrative structures and fates" (Assembling Flann O'Brien 113). Bonaparte, when he returns home that day, says to his mother -"I've heard that every fellow in this place is called Jams O'Donnell" - and reacts as follows when told that this is true to him as well- "If "tis true itself said I, I've no understanding of that truth" (The Poor Mouth 31). Thus, as Long suggests, that name acquired by Bonaparte is "associated with violence, trickery and arrest" (Assembling Flann O'Brien 116). Yet, the slight understanding of the situation is not associated with Bonaparte's acknowledgement of it, but rather to how he will use the name, as his own, in several situations in the novel which involve poor communication sequences. Namely, being imprisoned because of using this name, but also finding his father, in the following scene, thanks to this same name - "The name and the surname that's on me, said I, is also Jams O'Donnell. You're my father and it's clear that you've come out of the jug"' (124).

In the scene mentioned from An Béal Bocht, students are categorized through a name that becomes improper, a common noun that functions as a proper name. And "when a proper name is changed into a common noun, however, individuality and subjectivity are wholly denied. In An Béal Bocht we see a violent act of naming which works to bind and enslave but does so by naming without giving a name worthy of the name" (Long, "Translation" 81). As Derrida states, "personal proper names cannot be translated" ("Des Tours de Babel" 36), as there is an impracticability within the act of translating names. This is particularly portrayed in the school scene of chapter three, in the introduction and conversion of the Irish name into the English name, mediated by the violent act of the colonial norm. Still, Myles takes the category represented in this name, common noun to neutralize the people from Corkadoragha, and writes this name phonetically, as an Irish speaker would understand "Jams" and not the English standard "James". Both Irish and English, then, are confronted but not separated within this scene. On one hand, the English language tries to negate the position of Irish through physical and linguistic violence. The example of the children at school is an explicit illustration of concrete, but also symbolic violence, as translating and commissioning new English names to displace Irish names neutralizes the language and its users. ${ }^{8}$ Still, Irish resides in Corkadoragha just as their inhabitants.

This can be related to the following column featured in Cruiskeen Lawn, on June $19^{\text {th }}$, 1942 , - "Consider the word wheat. By its nourishment wheat gives you heat. And in addition to heat, wheat gives you something to eat. Get it?" (The Best of Myles 96). The narrator provides a linguistic account for a common word: "wheat". Yet, he does not offer any accurate meaning towards the significance or use of the word. The definition of the word is fallacious due to its remote association to reality and the relation with the rest of the words mentioned is entirely trivial, failing to provide any real meaning to the explanation. As Coulouma suggests, "O'Brien's games rely on the discrepancy between language, reference and usage, thus allowing ironic stances to pervade all levels of discourse" (60). The narrator, talking about the previous statement, then says - "I'm pretty deep, you know, sometimes" (The Best of Myles 96). Again, there is a certain knowledge provided that doesn't get understood completely, since the main figures involved do not comprehend, completely, the use of those words in their particular speech context. The question of true significance and the relationship with the reference are distanced to portray the complexity involved while communicating, both in An Béal Bocht with the colonial name imposition and in the column with the word "wheat". 


\section{5.- "misunderstanding"}

As a term, "misunderstanding" refers, primarily, to the misconception of something that has been said. To this extent, this term functions as an in-between among "faint-understanding" and "over-understanding", as it is the neutral misinterpretation over any meaning. Thus, "faintunderstanding" positions itself below this, as this is an incomplete comprehension, and "overunderstanding" being above, consists of the thought of a total and exaggerated acquisition of meaning.

The end of chapter three of An Béal Bocht narrates the visit of a gentleman from Dublin to Corkadoragha due to his interest in the Gaelic language, a clear parodic take on revivalists' doings to revitalise Irish. The Dublin Gentleman travels with recording equipment, a gramophone, in which to store folklore tales and all kinds of traditional stories. This archaeological fashion in which the gentleman sets off to Corkadoragha is, in the beginning, a failure, due to the lack of response from the inhabitants. Yet, one night, the gramophone started recording and after some time the gentleman left feeling happy about this, but the narrator says that "whatever word was uttered that night, came from our rambling pig" (The Poor Mouth 45).

The source of this misconception can be found in what is referenced as the belief of the gentleman about the Gaelic language - "He understood that good Gaelic is difficult but that the best Gaelic of all is well-nigh unintelligible" (44). This is augmented when the narrator tells that this man showed his recording to "the most learned ones of the continent" (44) and that they replied by saying that "they never heard any fragment of Gaelic which was so good, so poetic and so obscure as it and that were sure there was no fear for Gaelic while the like was audible in Ireland" (44-45). Certainly, there is a complete misunderstanding not only of the meaning of the sounds captured by the gramophone but, more importantly, of what Irish should be or how it should sound. As Long suggests, "throughout An Béal Bocht the position of the Irish language is problematised. While it is a human language that fills mouths with sweet words, it is also confused with the grunting of swine" (Assembling Flann O'Brien 187).

This scene is a representative illustration of O'Nolan's playful take on the political and cultural scenario around him. As it has already been mentioned, his writing exhibits both the caricaturised version of the Irish language acquired during the period thanks to nationalist devotion and O'Nolan's conception of the language. With the arrival of the Dublin gentleman to study Gaelic, there is "a complex - and noisome - contamination between the treatment the Irish language received by those who wished to protect it, and those who saw it as an anachronistic remnant of poverty and insularity" (Long, Assembling Flann O'Brien 124). In this manner, the depiction of the Irish language by the Dublin gentleman illustrates how language can be reduced, by scholars and outsiders, to a relic without meaning. First, the gentleman in Myles' novel approaches his interest in Irish as if he was carrying out scientific research. Still, this is augmented by the portrayal of Irish as something "well-nigh unintelligible" (The Poor Mouth 44), impossible to understand and distant. If those two approaches were not sufficient to mystify the language and condemn it to an exhibition shelf, those who hear these recordings, mistaking pig noises for a conversation in Irish, do not have any knowledge of the language whatsoever to refer to this as "so good, so poetic". Thus, the Irish language in eyes of others assumes the shape of an incomprehensible and distant relic, which is much referred to but inadequately understood.

In a short columned titled "Chat", published on June $10^{\text {th }}, 1942$, Myles' furthers the "misunderstanding" of a conversation by accentuating the misconception within the contents of the dialogue. Two voices who act as knowledgeable, but have no real understanding of their words, appear, once more, in the middle of a language exchange. One voice asks - "Does Proust affect you terribly?" (The Best of Myles 111). The first voice asks about a particular work of 
literature, À la recherche du temps perdu, playing with the elevated and refined connotations that underlay this particular text. When hearing the reply, this voice does not feel satisfied and furthers the query - "But surely... surely Swann ...?" (111). The other voice answers - "Ah yes ... If all his geese were Swanns..." (111). The second voice misunderstands the question and assimilates the name, mentioned by the first voice as a character to be taken into consideration, with the animal, as this is the simplest understanding of the term. As in other linguistic exchanges found in Cruiskeen Lawn, the speakers are self-conscious about their use of clichés and enjoy using them.

This brief dialogue rejoices, once more, over knowledgeable topics which are fairly treated. There is a depiction of voices that acknowledge certain wisdom over topics that appear elevated and are extremely uninformed or misinformed. That is the case with highly regarded literature as Proust's book in the column or the Irish language in An Béal Bocht. Both in the novel and in the column, the misinformed characters link their perceived knowledge in a certain manner that disables them to reflect on their sayings. That is, this misconception on knowledgeable topics is carried through a well-established bond that connects the speakers and these specific topics. By portraying this type of figures and conversations, Myles questions the real meaning of speech and how closely related, or not, this is to reality and the people in it, both in situations where a language, Irish, is expected to have a certain form or in dialogues where dignified topics are mentioned.

\section{6. "over-understanding"}

Finally, "over-understanding" refers to an exaggeration made over facts that are acquired partially but believed to be acquired correctly. In this case, the verbs "to boast" or "to brag" are a perfect illustration of the tone that this misconception might acquire. The easiness in which a misconception can be referred and, especially, reproduced is what distinguishes this type of understanding.

Chapter four of An Béal Bocht features a big feis in which members of the community and outsiders join to celebrate all things Irish. At the beginning of the celebration, the President of the Grand Feis opens the events by making a speech - "it delights my Gaelic heart to be here today speaking Gaelic with you at this Gaelic feis in the centre of the Gaeltacht. May I state that I am a Gael. I'm Gaelic from the crown of my head to the soles of my feet" (The Poor Mouth 54). This sets the tone of the speech, which will insist on the concept of being "Gaelic at heart". When talking about the idea of national identity in Ireland, Long asserts that "what was welcomed as truly Irish was just often roundly dismissed as utter fabrication" ("Irish stereotype" 37). This ridiculous discourse over the importance of being Irish, and how some people are not Irish enough, discloses a complete exaggeration and caricaturization of the term and the people involved in it, both the inhabitants of this imaginary Gaeltacht and the outsiders. According to Ó Conaire, "The Corca Dorcha feis is the closest O'Nolan comes to implying that the reality of life in the Gaeltacht is ignored by language revivalists" (108). Hence, in Myles' critique over language revivalists and in the scene from An Béal Bocht, an impossibility of reaching this "Gaelic" identity can be read. This form of collective self, the Gaels, shows an invention rather than a true identification with an existing group.

In the feis, the speech of the President of the celebration finishes as follows - "There is nothing in this life so nice and so Gaelic as truly true Gaelic Gaels who speak in true Gaelic Gaelic about the truly Gaelic language" (The Poor Mouth 54-55). Notice the use of repetition that accentuates the message already conveyed about the importance of "Gaelicism", because he, as all characters in the novel, "in its hyperbolic fictive space they play excessive, overwritten versions of themselves" (Long, Assembling Flann O'Brien 114). The speech in the feis continues as follows - "We must all be strongly in favour of Gaelic. Likewise, I don't think the 
university is in earnest about Gaelic. The commercial and industrial classes are not in favour of Gaelic. I often wonder whether anyone is in earnest about Gaelic" (The Poor Mouth 55). As in the account of the Dublin gentleman, this figure accentuates, as the narration takes place, a particular construction regarding the image of the Irish language, its setting and speakers.

Still, the relationship between the inhabitants of Corkadoragha and Irish is much more complicated than this portrayal of true Gaelicism. The idea of coherence in the use of one language is disruptive because "In The Poor Mouth, by contrast, the Gaels are far from noncoopted exemplars of native essence; instead, they are merely frustrated wanna-be collaborators in anglicization" (McKibben 110). There is nothing essentially Irish within the inhabitants, as suggested by the President of the Grand Feis, but a troublesome position where they are condemned through language misconceptions believed to be accurate both in the use of Irish by violent means at school, as in the first example, and by oblivious foreigners in the context of the feis. In this manner, there is no "Gaelicism" aside the fabrication expressed in the speech of the Grand Feis, emphasizing the idea that "Ireland is and was predicated on fakes, copies, farce and anachronisms" (Long, "Irish stereotype" 109).

A column from Cruiskeen Lawn titled by the name of "The Gaelic", published on January 11th, 1941, explores the complexity of Irish by using the same exaggerated tone as the President of the Grand Feis. It says - "A lady lecturing recently on the Irish language drew attention to the fact ... that, while the average English speaker gets along with a mere 400 words, the Irish-speaking peasant uses 4.000" (The Best of Myles 278). The overstatements are used, once more, to emphasize the difference in use between English and Irish and to highlight the context in which they are used. Thus, in Coulouma's words, Myles "questions intentional meaning and the status of the speaker" (70). In this case, the voice of the column accentuates the rural nature of Irish and implicates that English is surrounded by an urban setting. Still, this difference is mentioned to show that "your paltry English speaker apprehends sea-going craft through the infantile cognition which merely distinguishes the small from the big" (The Best of Myles 279), in opposition to the use of vocabulary in the Irish language. The exaggeration over a certain knowledge affects the portrayal of the dialogic reference, as in the fabricated Gaelicism mentioned in the Grand Feis and in the mention of the Irish language in the column.

\section{Conclusion}

O’Nolan's work, particularly An Béal Bocht and Cruiskeen Lawn, have displayed, aside from brilliant witticism, the cultural and social issues of his time. Particularly, those involving language, the Irish language, which exhibits nationalist political failure and social distortion. Language, as Derrida suggests, ensures the prolongation of tradition.

The great success around An Béal Bocht, along with its narrative style and concerns, was anticipated in the columns of Cruiskeen Lawn. Both works maintain a close relationship regarding the parodic treatment of Gaeltacht literature. And, especially, in portraying what O'Nolan thought Irish should be and what the society around him thought this was. His writing, thus, can be seen as a significant illustration of how dissimilar languages can coexist problematically.

The language issue can be read under three different types of language understanding that illustrate the complexity within the conjunction of the Irish and the English sphere. First, with "faint-understanding", illustrated by the young O'Coonassa at school with his poor understanding of English but acquiring a new English name, without the perception of the colonial norm behind, and the explanation of the word "wheat" in Cruiskeen Lawn. Then, with "misunderstanding", as the scene that narrates the gentleman that collects pig noises thinking that they are Gaelic tales and the lack of communication in a conversation in Cruiskeen Lawn. And, finally, with "over-understanding", when the President opens the Gaelic feis with a 
ridiculous speech about the language and a lady lecturing in the Gaelic talks about its vocabulary differences with English in Cruiskeen Lawn.

Consequently, these three terms can be found in specific scenes of An Béal Bocht as well as Cruiskeen Lawn, and exhibit O'Nolan's questioning of the pure and strict learning of language, Irish and English, which is saturated by complexity and ruled by coexistence. The two languages are implied several times over the texts, representing the useless attempt of English to neutralize Irish, through physical and linguistic violence. Still, Irish is represented as an incomprehensible and remote relic, often alluded but not quite comprehended. Likewise, Irish speakers, or Irish inhabitants, do not possess an essential quality of Irishness within them and they are placed in an ambivalent and oppressive position: they are responded with violence if they use Irish institutionally, at school, but praised by oblivious foreigners in a different context, such as that of the feis. In O'Nolan's work, thus, the disruptive force of Irish dwells in an in-between situation that abstains from, concerning its particular social and cultural situation, any type of institutional fixation and fossilization.

\section{Notes}

\footnotetext{
${ }^{1}$ The term "parody", in Bakhtin's words, can be understood in the following way: "a structured stylistic system that expresses the differentiated socio-ideological position of the author amid the heteroglossia of his epoch" (300). ${ }^{2}$ Ó Criomhthain's novel is also mentioned and cited repeatedly in Cruiskeen Lawn, i.e. the use of a small excerpt from the text (see page 276 of Flann O'Brien. The Best of Myles. Dublin: Dalkey Archive Press, 1999).

${ }^{3}$ For more about the composition of O'Nolan's early works and how they were perceived by readers see Taaffee, Carol. "Irreverence moving towards the blasphemous': Brian O'Nolan, Blather and Irish Popular Culture". Flann O'Brien: Problems with Authority. Eds. Ruben Borg, Paul Fagan, John McCourt. Cork: Cork University Press, 2017. 21-33.

${ }^{4}$ The use of Latin is repeated throughout the years in Cruiskeen Lawn. This association is particularly interesting because of the idea of a dead language that resides in both cases and how it is playfully used while referencing both Irish and Latin.

${ }^{5} \mathrm{He}$ thought that reviving Irish was "at the present rate of going and way of working”, but agreed with O'Casey that it was "essential, particularly for any sort of literary worker" (Letter to Sean O'Casey following praise for An Béal Bocht, April 13 $\left.{ }^{\text {th }}, 1942\right)$.

${ }^{6}$ This quotation from the first Cruiskeen Lawn column, October $4^{\text {th }}, 1940$, was extracted from the Irish Times archive (https://www.irishtimes.com\%2Fnewspaper\%2Farchive\%2F1940\%2F1004\%2FPg004.html\#Ar00406).

${ }^{7}$ This definition is taken from the online version of the Cambridge English Dictionary.

${ }^{8}$ For a study of the use of Law in the novel see Maebh Long. "The Trial of Jams O'Donnell: An Béal Bocht and the Force of Law". Flann O'Brien: Contesting Legacies. Eds. Ruben Borg, Paul Fagan and Werner Huber. Cork: Cork University Press, 2014. 181-194.
}

\section{Works Cited}

Bakhtin, Mikhail. The Dialogic Imagination: Four Essays. Austin: University of Texas Press, 1981.

Coulouma, Flore. Diglossia and the Linguistic Turn: Flann O'Brien's Philosophy of Language. Champaign: Dalkey Archive Press, 2015.

Cronin, Anthony. No Laughing Matter: The Life and Times of Flann O'Brien. New York: Fromm International, 1998.

Derrida, Jacques. "Des Tours de Babel". Difference in Translation. Ed. Joseph Graham. Ithaca: Cornell University Press, 1985. 
- "Who or What Is Compared? The Concept of Comparative Literature and the Theoretical Problems of Translation". Discourse 30. 1/2. Special Issue: "Who?" or "What?" - Jacques Derrida. (Winter \& Spring 2008): 22-53.

Donohue, Keith. The Irish Anatomist: A Study of Flann O'Brien. Washington DC: Academia Press, 2002.

Gillespie, Alana. “'Banjaxed and Bewildered': Cruiskeen Lawn and the Role of Science in Independent Ireland". Flann O'Brien: Contesting Legacies. Eds. Ruben Borg, Paul Fagan and Werner Huber. Cork: Cork University Press, 2014. 169-180.

Kager, Maria. "Lamhd Láftar and Bad Language: Bilingual Cognition in Cruiskeen Lawn". Flann O'Brien: Problems with Authority. Eds. Ruben Borg, Paul Fagan, John McCourt. Cork: Cork University Press, 2017. 54-70.

Kiberd, Declan. Inventing Ireland: The Literature of the Modern Nation. London: Vintage Press, 1996.

Long, Maebh. "No more drunk, truculent, witty, celtic, dark, desperate, amorous paddies!': Brian O'Nolan and the Irish Stereotype". Flann O'Brien: Problems with Authority. Eds. Ruben Borg, Paul Fagan, John McCourt. Cork: Cork University Press, 2017. 34-53. Assembling Flann O'Brien. London: Bloomsbury Publishing, 2014. "An Béal Bocht, Translation and the Proper Name". Flann O'Brien \& Modernism. Eds. Julian Murphet, Ronan McDonald and Sascha Morrell. London: Bloomsbury Academic, 2014. 77-91.

McKibben, Sarah. "A Parody of (Post) Colonial Irish Manhood". Research in African Literatures 34. 4 (2003): 96-114.

O'Brien, Flann. The Poor Mouth. London: Picador, 1975.

—. The Best of Myles. Dublin: Dalkey Archive Press, 1999.

O’Neill, Jamie. "Introduction". The Various Lives of Keats and Chapman. Including "The Brother”, by Flann O’Brien. New York: Thomas Dunne, 2005. XI-XIX.

Ó Conaire, Breandan. "Flann O'Brien, "An Béal Bocht" and Other Irish Matters". Irish University Review 3. 2 (1973): 121-140.

Taaffe, Carol. Ireland Through the Looking-Glass: Flann O'Brien, Myles na gCopaleen and Irish Cultural Debate. Cork: Cork University Press, 2008.

Received: 26 June 2019 Revised version accepted: 30 January 2020

Julieta Abella is a graduate student from Universidad de Buenos Aires. Since 2017, she holds the position of English Literature Teaching Assistant within the same university and in 2019 she won a Graduate Student Research Fellowship. She undertook academic and research stays in University College Cork and Trinity College Dublin, where she specialized in Irish literature. Moreover, she presented her work in various national and international conferences and is currently working on a research based on Irish identity issues in Brian O'Nolan's work. Currently, she is a Teaching Fellow, also at Universidad de Buenos Aires, and works as a translator and editor.

abellajulieta@outlook.com.ar 